\title{
The Sixth International Congress of Photography.
}

I) URING the period June 29-July 6 there was held in Paris an International Congress on Photography, the purpose of which was to consider questions of standardisation in both pure photography and cinematography. The last Congress was held in Brussels in I9IO, and was to have been succeeded by a Congress in London in I9I5, but unfortunately the War intervened.

One of the reasons for holding the Congress this year in Paris was that it is the centenary of the discovery-according to French claims-of photography by Nicéphore Niepce; at the same time a plaque to the memory of Daguerre was unveiled. Attending the Congress were delegates from the United States, Belgium, England, France, Germany, Holland, Italy, Japan, Spain, and other countries. It was especially noticeable that there was nothing wanting in the cordiality with which the Germans were received; political questions were entirely put aside, it being realised that all the members had met for the furtherance of a common cause. Discussions were carried on in English, French, and German.

The Congress was opened on Monday afternoon, June 29, by Prof. Fabry of the Sorbonne, who is at the same time the president of the French Photographic Society. One delegate from each of the countries represented was elected as vice-president, and these presided in turn at the various sessions. The general arrangements were in the hands of MM. Clerc, Labussière, and Lobel.

For some time previous to the Congress an English committee, appointed by the Royal Photographic Society, had been at work in drawing up recommendations with respect to: a standard light source; exposure mechanism; development and subsequent treatment; the measurement of density; and the interpretation and statement of results. These recommendations were submitted to the Congress committee in sufficient time for them to be translated into French and German and circulated among the members. Recommendations were also received from the Optical Society of America with respect to the standard light source. It is significant that these recommendations formed the main basis of discussion. Agreement was arrived at between the various interests represented, and definite resolutions, embodying most of the recommendations of the English committee, were passed, but will not come into force until after a period of six months. The einematography section was also able to harmonise the various points of view held by the different countries represented. An international executive sub-committee was appointed, with $M$. Clerc as secretary, and it was resolved that the next Congress should be held three years hence, and that the place of meeting should be, if possible, in London.

In addition to the various meetings of the sections there were functions of a less arduous character, including a reception at the Hotel de Ville de Paris by M. Guillaumin, President of the Municipal Council, and a soirée, in the large amphitheatre of the Sorbonne, to commemorate the centenary of the invention of photography, at which the President of the French Republic, M. Doumergue, was present. A visit was made to the works and studios of M. Gaumont, and there were motor-car excursions to Ermenonville, Chaalis, and Senlis, and to the forest and chateau of Fontainbleau. The actual proceedings of the Congress were terminated on Saturday, July 4, by the usual banquet.

\section{Fishery Investigations.}

THE Ministry of Agriculture and Fisheries has recently issued a report on sea fisheries for the years I9I9-23, the last one (for the period I9I 51918) being published in 1920. This is a great pity, because both reports have been so very interesting. The 1920 report gave an engrossing account of the part played by British fishermen in the War, while the present one (H.M.S.O., 1925, 3s. $6 d$. net) deals, in ar equally agreeable way, with the gradual settling down towards normal conditions of the sea-fishing industry. Statistical tables, summarising the catches made and other numerical results of the Ministry's work, have been issued each year, and the report now available discusses, in a general way, the information that has been collected. There is a very good summary of the scientific investigations made during the post-War years, and there are a number of clear financial statements showing the cost of the various kinds of work, administrative, developmental and scientific, undertaken by the Ministry.

Three parts of the Ministry's publication, "Fishery Investigations," have recently been published. No. 6 vol. 6. Ser. II., "The Annual Cycle in the Life of the Mature Cod in the North Sea," by Michael Graham and collaborators, deals with the investigations, biological and statistical, made during the last few years (H.M.S.O., 1924, I3s. net). No. 2, vol. 7, Ser. II., " Report on Exploratory Voyages to Lousy Bank and Adjacent Areas," by Lieut. Pawsey, G. T. Atkinson, and H. H. Goodchild, describes some very careful work done in the investigation of a new fishingbank north from Rockall (H.M.S.O., r 924 , 3s. net). No. 6, vol. 7, Ser. II.," Report on the English Plaice
Investigations in the North Sea during the Years I92I-I923," by J. O. Borley and Miss D. E. ThursbyPelham (H.M.S.O., I925, I3s. net), is a very clearly written and readable account of the investigations that have been made since the War on the apparent increase in the plaice stock of the North Sea as a result of the great decrease in fishing during the period of military operations and restrictions. The results of the international inquiries and the recommendations that were made are also given. It contains a very good bibliography and is a very important work.

Some notable publications of the International Council for the Exploration of the Sea have also appeared recently. Dr. Martin Knudsen has prepared a Bulletin Hydrographique (1924), dealing in a general way with the observations made during the years $1920-I-2-3$. Dr. Ed. le Danois has edited the Rapport Atlantique (Rapports et ProcèsVerbaux, vol. 35, January, 1925). This contains the results of the investigations made by the "Atlantic Slope Committee," and it includes a very interesting discussion of the transgressions of Atlantic oceanic water into the shallow European seas. There is a discussion of the relation of this oscillatory movement of superficial Atlantic water to the long periodic tides. Publication de Circonstance, No. 84 (I924), is a description, in English, by Messrs. Ostenfeld and Jespersen, of the "standard plankton net" which was to have been designed by the late $\mathrm{E}$. W. Nelson. The instrument is a modified "Nansen net," hauled in the way devised by Mr. H. J. Buchanan Wollaston of the English Fishery Investigations Staff. J. J.

No. 29 IO, VOL. I I 6 ] 